\title{
Manajemen Anestesi untuk Seksio Sesarea pada Pasien Eklampsia dengan Perdarahan Intrakranial
}

\author{
Chrismas Gideon Bangun*), Siti Chasnak Saleh ${ }^{* *}$, Sudadi $\left.{ }^{* * *}\right)$ \\ ${ }^{*}$ Departemen Anestesiologi dan Terapi Intensif Fakultas Kedokteran Universitas Sumatera Utara-RSUP H. Adam \\ Malik Medan, ${ }^{* *}$ Departemen Anestesiologi dan Terapi Intensif Fakultas Kedokteran Universitas Airlangga-RSUD \\ Soetomo Surabaya, ${ }^{* * *}$ Departemen Anestesiologi dan Terapi Intensif Fakultas Kedokteran Universitas Gadjah \\ Mada-RSUP Dr. Sardjito Yogyakarta
}

\begin{abstract}
Abstrak
Perdarahan intrakranial pada kehamilan adalah penyebab kematian utama pada pasien-pasien dengan eklampsia. Hipertensi, yang berkaitan dengan stroke iskemik dan stroke hemoragik, adalah tampilan utama. Penanganan definitif merupakan terminasi kehamilan dengan seksio sesarea. Namun, tidak tepat untuk memulai persalinan pada ibu yang tidak stabil, sekalipun terdapat gawat janin. Begitu kejang dapat dikendalikan, hipertensi berat ditangani dan hipoksia dikoreksi, persalinan dapat dimulai. Sasaran manajemen anestesia yang pertama yaitu pengendalian kejang, pengendalian tekanan darah, dan pencegahan peningkatan tekanan intrakranial. Anestesi umum merupakan pilihan pada pasien tidak sadar, atau penurunan kesadaran dengan tanda-tanda peningkatan tekanan intrakranial. Anestesia dicapai dengan inhalasi, opioid, relaksasi dan hiperventilasi secara hati-hati. Pada kasus ini seorang ibu 31 tahun, 55 kg, usia kehamilan 36-37 minggu datang ke rumah sakit dengan penurunan kesadaran dan riwayat kejang. Dijumpai sensorium E2M5V2, tekanan darah 180/100mmHg dan proteinuri 3+. Segera diputuskan dilakukan seksio sesarea dengan anestesi umum dan rapid sequence induction dengan fentanyl $50 \mathrm{mcg}$, propofol $100 \mathrm{mg}$ dan rocuronium $50 \mathrm{mg}$ intravena. Post operasi pasien dirawat di ICU, dilakukan head CT-Scan dan dijumpai perdarahan intrakranial di temporoparietal kanan. Penanganan perdarahan intrakranial diputuskan konservatif. Hari ke-3 pascabedah pasien diekstubasi dan pada hari ke-5 pasien dipindahkan ke ruangan dengan sensorium E3M5V2.
\end{abstract}

Kata kunci: seksio sesarea, eklampsia, perdarahan intrakranial

JNI 2021;10 (2): 119-126

\section{Management of Anesthesia for Eclampsia Caesarean Section Patient with Intracranial Bleeding}

\begin{abstract}
Intracranial haemorrhage in pregnancy is the leading cause of death in eclampsia patients. Hypertension, which is associated with both ischemic and hemorrhagic strokes, is the main feature. Definitive treatment is termination of pregnancy with cesarean section. However, it is not appropriate to start labor in an unstable mother, despite fetal distress. Once seizures can be controlled, severe hypertension is treated and hypoxia is corrected, labor may begin. The first anesthesia management goals are seizure control, blood pressure control, and prevention of increased intracranial pressure. General anesthesia is an option in the unconscious patient, or decreased consciousness with signs of increased intracranial pressure. Anesthesia is achieved with inhalation, opioids, relaxation and hyperventilation techniques carefully. In this case a 31-year-old mother, $55 \mathrm{~kg}$, 36-37 weeks' gestation comes to the hospital with a decrease in consciousness and a history of seizures. Found sensorium E2M5V2, blood pressure 180/100 $\mathrm{mmHg}$ and proteinuria 3+. Immediately, a cesarean section with general anesthesia and rapid sequence induction with fentanyl $50 \mathrm{mcg}$, propofol $100 \mathrm{mg}$ and rocuronium $50 \mathrm{mg}$ intravenously were performed. Post surgery the patient was treated in the ICU, head CT-Scan was performed and intracranial hemorrhage in the right temporoparietal was encountered. Management of intracranial hemorrhage was decided conservatively. The 3rd day postoperative the patient was extubated and on the 5th day the patient was transferred with E3M5V2 sensorium.
\end{abstract}

Key words: caesarean section, eclampsia, intracranial haemorrhage

This article is licensed under

Creative Commons Attribution-NonCommercial-ShareAlike 4.0 International License.

CChrismas Gideon Bangun, Siti C. Saleh, Sudadi

(2021) under the CC-BY-NC-SA license 


\section{JNI 2021;10 (2): 119-126}

\section{Pendahuluan}

Eklampsia, istilah yang berasal bahasa Yunani berarti persepsi cahaya yang aneh, sebagaimana hakikatnya yang berhubungan dengan gangguan penglihatan. Eklampsia didefinisikan sebagai adanya kejadian satu atau lebih kejang umum dan/atau koma setelah preeklampsia dan tidak adanya kondisi neurologik yang lain sebelumnya, sebelum, sewaktu, atau setelah persalinan Setiap wanita hamil dengan presentasi kejang di ruang gawat darurat harus dianggap sebagai eklampsia sampai terbukti tidak. ${ }^{1}$ Kejang biasanya terjadi spontan didahului oleh kongesti wajah dengan menonjolnya mata, dari mulut keluar buih, dan lidah dapat tergigit. Secara tipikal tampak dimulai sebagai kedutan pada wajah diikuti fase tonik yang bertahan selama 15 sampai 20 detik. Kemudian berlanjut kepada fase klonik umum dengan apneu, yang dapat bertahan mendekati 1 menit. Nafas kemudian berlanjut cepat dan dalam dan pasien masuk dalam keadaan post iktal (kesadaran yang berubah seperti setelah terjadi epilepsi), dengan waktu koma yang bervariasi. Henti kardiorespirasi dan aspirasi paru isi lambung dapat memperburuk kejang. ${ }^{2}$ Selama tahun 2003-2005 Confidential Enquiry into Maternal and Child Health (CEMACH) melaporkan, 18 kematian akibat pre-eklampsia dan eklampsia; $67 \%$ akibat gangguan serebrovaskuler (10 perdarahan intrakranial, ICH; dan 2 infark serebral). ${ }^{3}$

Perdarahan intrakranial yang berkaitan dengan kehamilan biasanya disebabkan oleh pre-eklampsia, eklampsia, atau malformasi serebrovaskular, dan beberapa studi menunjukkan bahwa perdarahan intrakranial pada kehamilan mungkin adalah penyebab kematian utama pada pasien-pasien pre-eklampsia. Hipertensi, yang berkaitan dengan kedua stroke iskemik dan hemoragik, adalah tampilan utama dari pre-eklampsia. ${ }^{4}$ Risiko terjadinya stroke selama kehamilanadalahrendah,namunbilastroketerjadi, morbiditas dan mortalitas dari komplikasinya tinggi. ${ }^{5}$ Perdarahan intrakranial diklasifikasikan secara anatomi sebagai ekstradural, subdural, subarakhnoid atau intraserebral. Perdarahan intraserebral spontan pada pasien obstetri paling sering disebabkan oleh malformasi arteriovenous, hipertensi atau sumbatan vena. ${ }^{6}$

Pada eklampsia terjadi kehilangan autoregulasi aliran darah otak (ADO/CBF: cerebral blood flow) menyebabkan peningkatan ADO membuat sebagian segmen pembuluh darah dilatasi, iskemik, dan meningkat permeablitasnya. Vasospasme serebral, iskemia, edema, perdarahan, dan ensefalopati hipertensif adalah patogenesis kejang yang mungkin terjadi. ${ }^{7}$ Sasaran manajemen anestesia yang pertama adalah pengendalian kejang dan pengendalian tekanan darah (penanganan lebih agresif harus dilakukan jika tekanan diastolik melebihi 110 $\mathrm{mmHg}$ ). Kemungkinan peningkatan tekanan intrakranial (TIK) tidak perlu dikhawatirkan oleh anestesiolog bila pasien tetap sadar, alert, dan bebas kejang. Sementara koma yang menetap dan adanya defisit neurologis lokal mengindikasikan adaanya patologi intrakranial yang penting, yang mempengaruhi pertimbangan manajemen anestesi. Penting juga mempertahankan keseimbangan cairan, keseimbangan cairan masukdan keluar harus dijaga. Oksigenasi ibu dipantau dengan pulse oximetry kontinyu. Produk-produk darah juga perlu tersedia, dan studi koagulasi harus dilakukan walaupun hitung trombosit dalam batas normal. Kemudian preloading diberikan secukupnya jika diduga hipovolemia atau setelah terapi vasodilator. ${ }^{2}$

Konsep mendasar dari pengendalian kejang adalah mencegah cedera pada ibu, memastikan oksigenasi, memberi support kardio-respirasi, dan mencegah aspirasi. Magnesium sulfat $\left(\mathrm{MgSO}_{4}\right)$ adalah pilihan obat anti kejang. ${ }^{2}$ Penanganan definitifnyayaitu terminasi kehamilan dengan bedah sesar. Namun, tidaklah tepat untuk memulai persalinan pada ibu dengan kondisi yang tidak stabil, walaupun terdapat gawat janin sekalipun. Setelah kejang dapat dikendalikan, hipertensi berat tertangani dan hipoksia terkoreksi, maka terminasi kehamilan dapat segera dimulai. Anestesi umum merupakan pilihan pada pasien tidak sadar, atau adanya penurunan kesadaran dengan tanda-tanda peningkatan tekanan intrakranial. Anestesia dicapai dengan anestesika 
inhalasi, opioid, relaksasi dan hiperventilasi secara hati-hati. Hal-hal yang harus diperhatikan adalah edema jalan nafas dan kemungkinan kesulitan manajemen jalan nafas. Respon hipertensi berlebihan terhadap intubasi trakea juga harus diwaspadai. Kemudian adanya interaksi obat antara magnesium dan pelumpuh otot, magnesium menyebabkan terhambatnya influks kalsium sehingga kerja pelumpuh otot dapat memanjang. Dosis rendah obat anestesi volatil halogen dapat mencegah awareness. Ekstubasi dilakukan dalam posisi lateral kiri jika pasien sadar penuh atau pasien dipindahkan ke ICU untuk support ventilator tergantung kondisi sebelum operasi dan kejadian intraoperatif. ${ }^{2}$ Pertimbangan anestesia pada kasus preeklampsiaeklampsia harus melihat kejadian yang sebenarnya terjadi pada serebrovaskuler otak. Walaupun terjadi perubahan serebrovaskuler di otak, tidak selalu memunculkan adanya kenaikan tekanan intrakranial yang menjadi pertimbangan penting pemilihan tindakan dan obat yang dipakai dalam anestesi. Bila terdapat kenaikan tekanan intrakranial, anestesi umum dengan kaidah neuroanestesi merupakan pilihan. ${ }^{2}$

\section{Kasus}

\section{Riwayat Penyakit}

Seorang wanita, 31 tahun, $55 \mathrm{~kg}$, G2P1A0 usia kehamilan 36-37 minggu datang ke rumah sakit dengan penurunan kesadaran setelah mengalami kejang. Berdasarkan alloanamnesis, pasien telah mengalami 3 kali kejang sebelum dirujuk ke rumah sakit.

\section{Pemeriksaan Fisik}

Pada pemeriksaan di ruang gawat darurat didapatkan nafas $28 \mathrm{kali} / \mathrm{menit}$, tekanan darah 180/100 $\mathrm{mmHg}$, nadi $110 \mathrm{kali} / \mathrm{menit}$, sensorium GCS E2M5V2, diberikan oksigen dengan sungkup dan dipasang infus. Pupil bulat anisokor, ukuran $4 \mathrm{~mm}$ (kanan) dan $2 \mathrm{~mm}$ (kiri). Ditemukan lateralisasi kiri, dan ditemukan edema pada wajah dan tungkai.

\section{Pemeriksaan Penunjang \\ Pemeriksaan darah}

Hasil pemeriksaan darah kadar hemoglobin
$11,5 \mathrm{mg} / \mathrm{dL}$, hematokrit $34,5 \%$, leukosit $21.000 /$ $\mathrm{mm} 3$, trombosit $185.000 / \mathrm{mm} 3$, ureum $12,7 \mathrm{mg} /$ $\mathrm{dL}$, kreatinin 0,8mg/dL, Na $143 \mathrm{mmol} / \mathrm{L}, \mathrm{K} 3,2$ $\mathrm{mmol} / \mathrm{L}, \mathrm{Cl} 112 \mathrm{mmol} / \mathrm{L}$, PTT 14,6 (kontrol 11,9), aPTT 72,4/(kontrol 27,7) SGOT 62, SGPT 42 , albumin $3,2 \mathrm{mg} / \mathrm{dl}$. Pada pemeriksaan urin ditemukan proteinuria $3+$.

\section{Penanganan di Ruang Emergensi}

Pasien diposisikan supine dengan head-up 1020 derajat, diberikan oksigen dengan nasal kanul $2 \mathrm{~L} /$ menit, dan panggul kanan diganjal. Diberikan $\mathrm{MgSO}_{4} 4 \mathrm{~g}\left(10 \mathrm{ml}\right.$ larutan $\mathrm{MgSO}_{4}$ 40\%), diencerkan dan diberikan dalam 20 menit. Setelah itu diberikan rumatan $6 \mathrm{~g}$ dalam $\mathrm{NaCl}$ 0,9\% 28 tetes/menit. Bila tekanan darah sistolik masih diatas $180 \mathrm{mmHg}$ direncanakan pemberian Nifedipin $10 \mathrm{mg}$ sublingual. Selama di unit gawat darurat tekanan darah tetap stabil. Segera direncanakan untuk terminasi kehamilan darurat dengan cara bedah sesar dan setelah informed consent pasien didorong ke kamar operasi. Setengah jam sebelum operasi diberikan sirup Antasida sebanyak dua sendok makan.

\section{Pengelolaan Anestesi}

Pasien diposisikan supine dengan head up 2030 derajat, panggul kanan diganjal. Dilakukan preoksigenasi dengan sungkup muka diletakkan diwajah dengan oksigen $8 \mathrm{~L} / \mathrm{menit}$, sambil dilakukan desinfeksi daerah operasi dan draping. Intubasi dilakukan dengan rapid sequence induction dengan fentanyl $50 \mathrm{mcg}$, propofol 100 $\mathrm{mg}$ dan rocuronium $50 \mathrm{mg}$ intravena. Dilakukan intubasi dengan pipa endotrakheal (endotracheal tube/ETT) ukuran 6,5mm. Setelah ETT dipastikan posisinya dan difiksasi, insisi dimulai oleh operator. Rumatan anestesi diberikan isoflurane $0,8 \%$ dan $\mathrm{N}_{2} \mathrm{O}+\mathrm{O}_{2}: 2 \mathrm{~L} /$ menit $+2 \mathrm{~L} /$ menit. Mesin anestesi di-setting dengan frekuensi nafas 14 kali per menit dan volume tidal $450 \mathrm{ml}$. Fentanyl ditambahkan $50 \mathrm{mcg}$ setelah bayi lahir. Bayi lahir sekitar 8 menit setelah induksi, dengan APGAR score 7/9. Hemodinamik selama operasi stabil (Tabel 1). Operasi berlangsung selama 45 menit.

\section{Pengelolaan Pascabedah}

Post operasi pasien dirawat di ICU dengan ventilator. Berdasarkan pemeriksaan kesadaran 


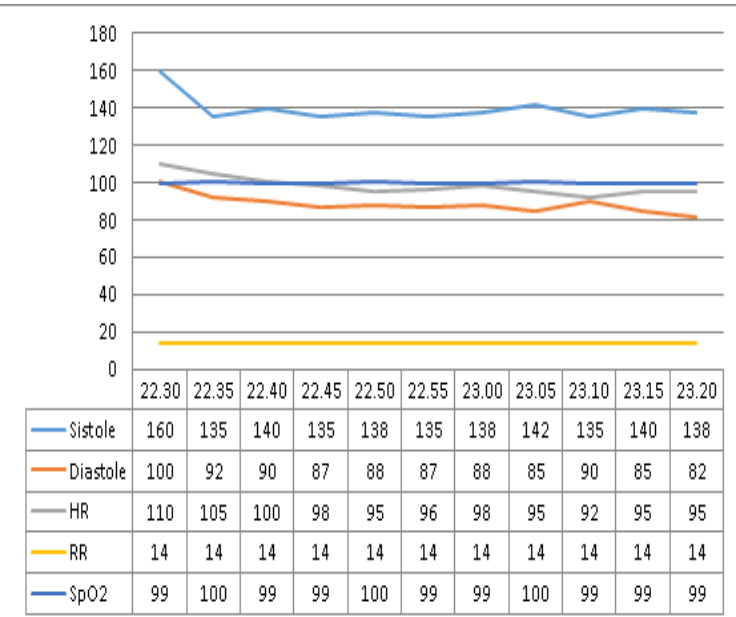

Tabel 1. Monitoring Durante Operasi

Keterangan: $\mathrm{HR}$ : heart rate, $\mathrm{RR}$ : respiratory rate, $\mathrm{SpO}_{2}$ : oksigen saturasi perifer

pasien belum menunjukkan perbaikan (GCS E2M5Vt), kemudian dilakukan head CTScan dan dijumpai perdarahan intrakranial di temporoparietal kanan. (Gambar 1.) Pasien kemudian dikonsultasikan ke bagian bedah saraf, diputuskan penanganan ICH secara konservatif. Dilakukan pemasangan kateter vena sentral (central venous catheter/CVC) di vena subklavia kanan. Kemudian dilakukan roentgen thorax AP dengan hasil tidak dijumpai kelainan pada paru dan jantung, ujung CVC berada di atrium kanan.

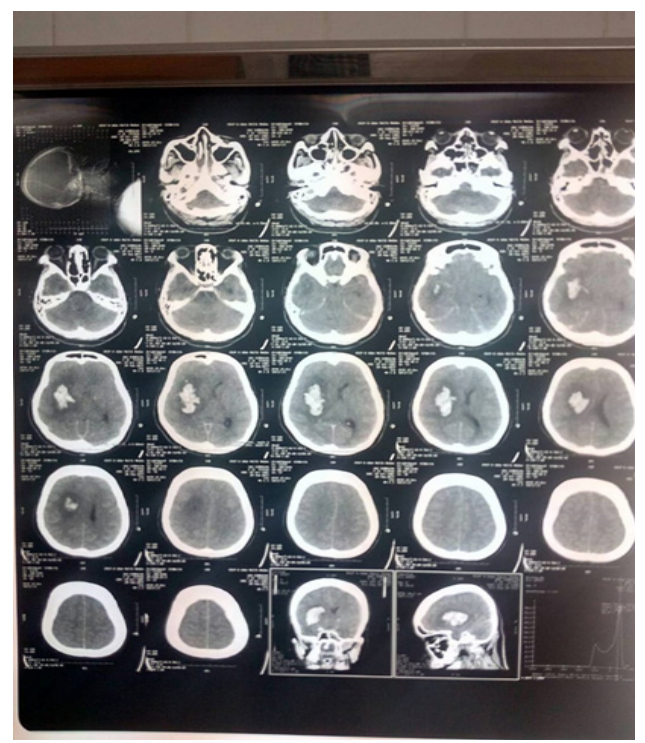

Gambar 1. Hasil Head CT-Scan. Terdapat Perdarahan Intrakranial di Temporo-parietal kanan.

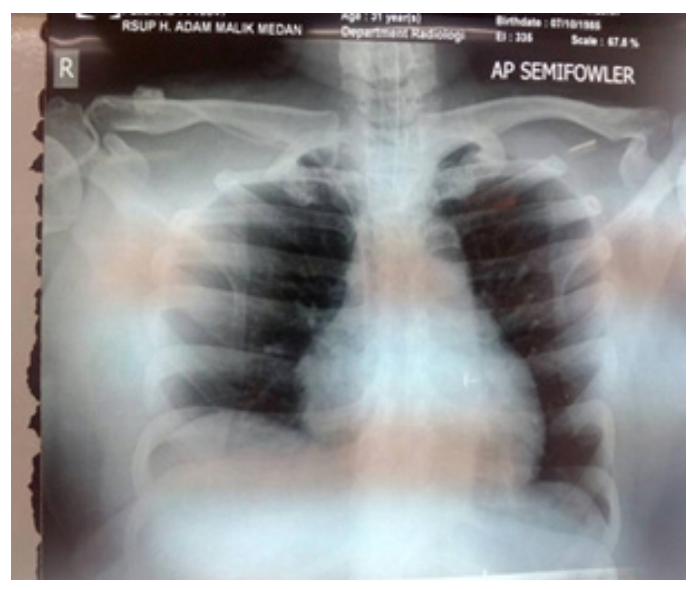

Gambar 2. Hasil Foto Thorax AP. Tidak Dijumpai Kelainan pada Paru dan Jantung.

(Gambar 2).

Follow-up Pasien di Unit Rawat Intensif

Hari ke-1:

Airway bebas terintubasi, kontrol ventilator modus SIMV 14, RR 16 kali per menit, TV 450ml, $\mathrm{FiO}_{2}$ 40\%, $\mathrm{SpO}_{2}$ 98-99\%, TD 118-165/75-94mmHg, HR 72-89 kali per menit, T $36,5^{\circ} \mathrm{C}$. Sensorium dalam sedasi, abdomen supel, urin output $80 \mathrm{cc} /$ jam. Terapi: head up 30 derajat, diet sonde 1800kkal, RL selang-seling $\mathrm{NaCl}$ 0,9\% 20 tetes per menit, sedasi dengan fentanil $30 \mathrm{mcg} / \mathrm{jam}$. Hari ke-2:

Airway bebas terintubasi, kontrol ventilator modus SIMV 8, RR 20 kali per menit, TV 450ml, $\mathrm{FiO}_{2}, 30 \%, \mathrm{SpO}_{2}$ 98-99\%, TD 118-170/82-95 $\mathrm{mmHg}$, HR 75-90 kali per menit, $\mathrm{T} 36,5^{\circ} \mathrm{C}$. Sensorium E2M5V2, abdomen supel, urin output 80cc/jam. Terapi: head up 30 derajat, diet sonde 1800kkal, RL selang-seling $\mathrm{NaCl}$ 0,9\% 20 tetes per menit, sedasi dengan Fentanil $30 \mathrm{mcg} / \mathrm{jam}$. Hari ke-3:

Airway bebas terintubasi, kontrol ventilator modus SIMV 6, RR 20 kali per menit, TV 450ml, $\mathrm{FiO}_{2} 30 \%$, TD 120-165/82-95 mmHg, HR $72-88$ kali per menit, T $36,5^{\circ} \mathrm{C}$. Sensorium E3M5V2, abdomen supel, urin output 80cc/jam. Terapi: head up 30 derajat, diet sonde 1800kkal, RL selang-seling $\mathrm{NaCl} 0,9 \% 20$ tetes per menit, sedasi dihentikan, disconnect ventilator, $\mathrm{O}_{2}$ via T-piece 6 liter per menit. Setelah 2 jam, RR 20 kali per menit, TD 145/89mmHg, HR 88 kali per menit, sensorium E3M5V2, gag refleks baik, dilakukan ekstubasi, $\mathrm{O}_{2}$ dari 
sungkup NRM 6 liter per menit, $\mathrm{SpO}_{2}$ 98-99\%. Hari ke-4:

Airway bebas, nafas spontan dengan $\mathrm{O}_{2}$ nasal kanul 2 liter per menit, $\mathrm{SpO}_{2}$ 98-99\%. TD 130155/75-90mmHg, HR 78-85 kali per menit, sensorium E3M5V2.

Hari ke 5:

Pada hari ke-5 pasien dipindahkan ke ruangan masih dengan sensorium E3M5V2 dan lateralisasi kiri masih dijumpai.

\section{Pembahasan}

Peran anestesiolog dalam eklampsia adalah membantu mengendalikan dan mencegah kejang berikutnya, mengendalikan tekanan darah, menjamin jalan nafas bebas, mencegah komplikasi lebih besar, memberikan labor analgesia dan memberikan anestesi untuk bedah sesar. ${ }^{2}$ Penanganan hipertensi harus segera dilakukan untuk mengurangi risiko perdarahan intrakranial ibu. Labetalol oral dan metildopa direkomendasikan sebagai obat lini pertama jika tekanan darah sistolik mencapai $150-160 \mathrm{mmHg}$. Jika terdapat pre-eklampsia berat penanganan dapat labetalol oral atau intravena, nifedipin oral, hidralazin intravena atau kombinasi untuk mencapai MAP $<125 \mathrm{mmHg}$.

Penanganan hipertensi yang berlebihan dapat menyebabkan gangguan pada janin akibat perfusi plasenta yang buruk. $^{8}$ Pada kasus ini pasien tiba di ruang emergensi dengan penurunan kesadaran dan hipertensi dengan tekanan darah 180/100 $\mathrm{mmHg}$. Setelah diberikan magnesium sulfat untuk mencegah kejang berikutnya, tekanan darah dapat dikendalikan, sehingga tidak memerlukan antihipertensi tambahan seperti nifedipin sublingual. Magnesium sulfat merupakan obat pilihan untuk mengurangi risiko kejang pada pre-eklampsia berat, mencegah timbulnya kejang baru dan mengurangi berulangnya kejang. Sifat vasodilator dari magnesium diduga dapat melawan vasospasme serebral dan meningkatkan aliran darah otak, sehingga mencegah timbulnya kejang. ${ }^{9}$ Dosis magnesium sulfat didapatkan dari regimen Collaborative Eclampsia Trial-bolus 4g selama 10 menit diikuti dengan infus $1 \mathrm{~g} / \mathrm{jam}$ sampai 24 setelah persalinan. Dosis rumatan dihentikan atau dikurangi menjadi $0,5 \mathrm{~g} / \mathrm{jam}$ bila pasien oliguris atau jika kadar magnesium serum melebihi kadar terapeutik. Jika kejang berulang, bolus 2-4g diberikan selama 10 menit. $^{10}$

Hingga saat ini, masih sedikit diketahui tentang faktor yang mempengaruhi prognosis perdarahan intrakranial pada kehamilan dan nifas. Berdasarkan laporan sebelumnya, para ahli bedah saraf telah memikirkan apakah penanganan perdarahan serebral (seperti misalnya penanganan konservatif) memiliki dampak yang berbeda. Hasil penelitian yang dilakukan dilaporkan tidak memiliki efek signifikan dari penanganan bedah: dari 18 kasus ICH sewaktu kehamilan dan nifas, 6 menjalani intervensi neurosurgikal dengan mortalitas maternal dan fetal sebanyak $16,67 \%$ untuk keduanya, sementara 12 yang menjalani penanganan konservatif mortalitas maternal dan fetal sebanyak $46,17 \%$ dan $45,46 \% .^{11}$ Hiperventilasi sering dilakukan selama prosedur bedah saraf untuk menghasilkan hipokarbia, yang menyebabkan vasokonstriksi, pengurangan volume darah intrakranial, dan penurunan tekanan intrakranial. Pada pasien hamil, hal ini dapat menyebabkan penurunan transfer oksigen ke plasenta; namun hal ini semestinya tidak signifikan pada hiperventilasi ringan $\left(\mathrm{PaCO}_{2} 30\right.$ $35 \mathrm{mmHg}$ ). Hipokarbia berat harus dihindari. ${ }^{12}$ Secara fisiologis ventilasi meningkat sewaktu kehamilan, tekanan karbon dioksida pada arteri $\left(\mathrm{PaCO}_{2}\right)$ normal bertahan pada $30-32 \mathrm{mmHg}$. Hiperventilasi terkontrol untuk mengurangi tekanan intrakranial masih merupakan pilihan pada meningkatnya tekanan intrakranial secara akut. Walaupun efek klinis hiperventilasi pada aliran darah plasenta masih diperdebatkan, hiperventilasi berat $\left(\mathrm{PaCO}_{2}<25 \mathrm{mmHg}\right)$ dapat menyebabkan vasokonstriksi arteri uterina dan pergeseran ke kiri kurva disosiasi oksihemoglobin ibu. ${ }^{13}$ Maka disarankan $\mathrm{PaCO}_{2}$ ibu dipertahankan pada kisaran $25-30 \mathrm{mmHg}$.

Anestesi umum dengan intubasi untuk tindakan bedah persalinan masih penting dalam beberapa hal tertentu. Indikasi anestesi umum termasuk abrupsi plasenta, koagulopati, hitung trombosit kurang dari $80.000-100.000 / \mathrm{uL}$ pada pasien 
preeklampsia dan eklampsia, edema paru berat, eklampsia, dan gawat janin. Anestesi umum pada preeklampsia dan eklampsia dapat meningkatkan risiko hipertensi, aspirasi, sumbatan jalan nafas, dan depresi neonatus sementara; risiko kematian ibu dari anestesi umum hampir 7 kali dari anestesi regional. ${ }^{14}$ Kesulitan jalan nafas merupakan salah satu masalah utama anestesi umum pada ibu hamil karena kehamilan menyebabkan edema pada jalan nafas dan mudah berdarah, gerakan leher terbatas, dan membesarnya payudara karena obesitas pada kehamilan, yang dapat mempersulit laringoskopi dan intubasi. ${ }^{15}$ Faktor-faktor ini dapat menaikkan nilai skor Mallampati menjadi 3 dan 4. Bahkan, kesulitan intubasi setelah induksi anestesi umum delapan kali lebih besar daripada populasi umum, dan salah satu penyebab tingginya morbiditas dan mortalitas. ${ }^{16}$ Adanya risiko yang berkaitan dengan ventilasi paru atau aspirasi gaster, walaupun pasien sudah puasa, karena pengosongan lambung yang memanjang. Sehingga, anestesi umum harus dilakukan dengan rapid sequence induction. Sebelum induksi anestesi, pasien diposisikan supine dengan pendorongan uterus ke kiri, dan denitrogensisasi, untuk memastikan oksigenasi ibu. ${ }^{17}$

Berikut adalah rekomendasi teknik anestesi umum pada ibu dengan eklampsia: ${ }^{18}$

1. Pasang kanul arteri radialis untuk monitor tekanan darah kontinu.

2. Pasang akses intravena besar untuk antisipasi perdarahan postpartum.

3. Pastikan berbagai ukuran pipa endotrakeal dan perlengkapan sulit intubasi.

4. Berikan antagonis reseptor $\mathrm{H} 2$ dan metoklopramid intravena 30-60 menit sebelum induksi anestesi.

5. Berikan antasida nonpartikel per oral 30 menit sebelum induksi.

6. Denitrogenasi (3 menit bernapas biasa atau 8 kali bernapas dalam dengan oksigen $100 \%$ menggunakan sungkup muka).

7. Beri labetalol (10 mg iv bolus) untuk mentitrasi penurunan tekanan darah sampai 140/90 $\mathrm{mmHg}$ sebelum induksi anestesi. Labetalol merupakan obat pilihan, karena onsetnya lambat dan durasinya panjang. Bila tidak tersedia, tidak respon atau kontraindikasi dengan labetolol dapat digunakan hidralazin atau nikardipin, sodium nitroprusid (SNP) atau infus nitrogliserin. Pemberian SNP dan nitrogliserin harus hati-hati, karena berefek pada preload, sedangkan input cairan harus dibatasi. Nikardipin diberikan dengan dosis $15-30 \mathrm{mcg} / \mathrm{kgbb}$ intravena. Karena sifatnya yang arterioselektif (tidak ada efek pada kapasitan vena atau preload), nikardipin tidak menurunkan tekanan darah dengan cepat dibandingkan dengan SNP dan nitrogliserin. Dapat juga diberikan $\mathrm{MgSO}_{4}$ intravena bolus $30-45 \mathrm{mg} / \mathrm{kgbb}$ segera setelah induksi.

8. Monitor denyut jantung janin.

9. Lakukan rapid sequence induction (RSI) dengan propofol $2-2,8 \mathrm{mg} / \mathrm{kgbb}$ dan pelumpuh otot kemudian lakukan laringoskopi.

10. Pemeliharaan anestesi dengan obat anestesi volatil atau propofol intravena dan oksigen $100 \%$ sebelum lahir bayi. Bila bayi telah lahir, turunkan dosis obat anestesi volatil atau propofol untuk mengurangi risiko atoni dan berikan opioid dengan atau tanpa benzodiazepin. Sebaiknya tidak memberi tambahan pelumpuh otot nondepoler.

11. Pada akhir operasi, reverse pelumpuh otot nondepoler dan dapat diberikan lagi labetolol 5-10 mg intravena bolus untuk mencegah hipertensi akibat ekstubasi.

Pasien yang tidak kembali secara neurologis (tidak sadar/awake atau concious) sebaiknya tetap terintubasi dan dimonitor di ICU. Bila penurunan kesadaran menetap, evaluasi neurologis lebih lanjut dengan elektroensefalografi dan imaging otak perlu dilakukan untuk menyingkirkan masalah neurologis lain yang mendasari. ${ }^{18}$ Jika anestesi umum harus dilakukan, menghindari lonjakan tekanan darah, terutama saat laringoskopi dan intubasi, harus dilakukan karena hipertensi berat dapat meningkatkan risiko morbiditas dan mortalitas ibu secara signifikan, termasuk perdarahan serebral. Perhatian harus ditujukan untuk memastikan kedalaman anestesi dan persiapan terhadap perubahan tekanan darah sewaktu intubasi, bahkan saat adanya gawat janin, karena perdarahan 
intrakranial adalah penyebab utama kematian. ${ }^{5}$ Untuk mengurangi respon terhadap laringoskopi, opioid kerja singkat dan antihipertensi seperti remifentanil, esmolol, dan nitrogliserin dapat bermanfaat, dan kelanjutan infus magnesium dapat dipertimbangkan. Remifentanil telah terbukti mengurangi laju nadi, tekanan darah dan respon katekolamin terhadap laringoskopi dan intubasi endotrakeal. ${ }^{19}$ Dilaporkan bahwa pada 15 ibu yang menjalani bedah sesar elektif, mendapat Fentanyl $1 \mathrm{mcg} / \mathrm{kg}$ intravena, tidak dijumpai depresi nafas pada bayi, dan seluruh penilaian neurologis dan perilaku bayi normal pada 4 jam dan 24 jam setelah lahir. ${ }^{20}$ Pada pasien ini diberikan fentanyl $1 \mathrm{mcg} / \mathrm{kgBB}$, pada saat intubasi tidak dijumpai peningkatan tekanan darah bermakna, dan tetap stabil selama operasi. Pada bayi juga tidak ditemukan depresi nafas yang bermakna.

\section{Simpulan}

Penanganan hipertensi harus segera dilakukan untuk mengurangi risiko perdarahan intrakranial ibu. Magnesium sulfat merupakan obat pilihan untuk mengurangi risiko kejang pada preeklampsia berat, mencegah timbulnya kejang baru dan mengurangi berulangnya kejang. Pengendalian hipertensi berat dapat diberikan labetalol oral atau intravena, nifedipin oral, hidralazin intravena atau kombinasi untuk mencapai MAP $<125 \mathrm{mmHg}$. Berdasarkan penelitian sebelumnya tidak didapatkan perbedaan bermakna penanganan perdarahan intrakranial secara bedah maupun konservatif. Walaupun anestesi umum bila dibandingkan dengan anestesi regional pada kasus obstetri lebih tinggi morbiditas dan mortalitasnya, namun anestesi umum adalah pilihan pada pasien tidak sadar, atau penurunan kesadaran dengan tandatanda peningkatan tekanan intrakranial.

Saat anestesi umum dilakukan, menghindari lonjakan tekanan darah, terutama saat laringoskopi dan intubasi, dan kedalaman anestesi harus dipertahankan, perubahan tekanan darah selama operasi harus dapat dikendalikan. Pemberian opioid dosis rendah seperti fentanyl maupun remifentanil aman untuk neonatus, dan pemberian dapat diulang pada ibu setelah bayi lahir. Perdarahan intrakranial, walaupun jarang dijumpai, merupakan penyebab penting dari morbiditas dan mortalitas pada kehamilan. Keputusan pemberian terapi harus berdasarkan prinsip yang sama seperti pada pasien tanpa kehamilan dengan perhatian bahwa kehamilan memiliki kondisi khusus tertentu. Terapi definitifnya adalah terminasi. Bagaimanapun, tidak pantas untuk melahirkan pada kondisi ibu yang tidak stabil walaupun ada fetal distress. Setelah kejang terkontrol, hipertensi berat telah diterapi dan hipoksia terkoreksi, terminasi kehamilan dapat dipercepat. Manajemen pemberian cairan bersamaan dengan pemberian magnesium dan terapi antihipertensi dengan pengawasan ketat terhadap hemodinamik harus dilanjutkan pada pasca persalinan.

\section{Daftar Pustaka}

1. Cunningham FG, Leveno KJ, Bloom SL, Hauth JC, Rouse DJ. Williams Obstetrics. Pregnancy hypertension. 23rd ed. Chap. 34, New York: McGraw-Hill; 2010:706-56.

2. Parthasarathy S, Hemanth Kumar VR, Sripriya R, Ravishankar M. Anesthetic management of a patient presenting with eclampsia. Anesth Essays Res 2013;7:30712.

3. Polley LS. Hypertensive disorder. Dalam: Chesnut DH, Polley LS, Tsen LC, Wong, CA, editors. Chesnut's Obstetric Anesthesia Principles and Practice. 4th ed. Philadelphia: Mosby Elsevier; 2009: 975-1007.

4. Martin JN, Bernstein PS, Barton JR. Stroke and severe preeclampsia and eclampsia: paradigm shift focusing on systolic blood pressure. Obstet Gynecol 2005;105:246-54.

5. Scott CA, Bewley S, Rudd A, Spark P, Kurinczuk JJ, Brocklehurst P, et al. Incidence, risk factors, management, and outcomes of stroke in pregnancy. Obst Gynecol. 2012;120(2 Pt 1):318-24. 
6. Fairhall JM, Stoodley MA. Intracranial haemorrhage in pregnancy. Obstetric Medicine 2009;2:120-2.

7. Barton JR, Sibai BM. Cerebral pathology in eclampsia. Clin Perinatol 1991;18:891-910.

8. James PR. Management of hypertension before, during and after pregnancy. Heart 2004; 90: 1499-504.

9. Altman D, Carroli G, Duley L, Farrell B, Moodley J, Neilson J, et al. Do women with preeclampsia, and their babies, benefit from magnesium sulphate? The Magpie trial: a randomised, placebocontrolled trial. Lancet 2002; 359: 1187-90.

10. The Eclampsia Trial Collaborative Group. Which anticonvulsant for women with eclampsia? Evidence from the Collaborative Eclampsia Trial. Lancet 1995; 345:1455-63

11. Liu XJ, Wang S., Zhao YL, Zhang D, Zhao J Z. A single-center study of hemorrhagic stroke caused by cerebrovascular disease during pregnancy and puerperium in China. Int J Gynaecol Obstet 2011;113: 82-3.

12. Kuczkowski KM. Nonobstetric surgery during pregnancy: what are the risks of anesthesia? Obstet Gynecol Surv 2004;59:52-6.

13. Low JA, Boston RW, Cerveneko FW. Effect of low maternal carbon dioxide tension on placental gas exchange. Am J Obstet Gynecol 1970;106:1032-41.
14. Hawkins JL. Maternal morbidity and mortality: Anaesthetic causes. Can J Anaesth. 2002;49 Suppl 1:R24-8.

15. Practice guidelines for pulmonary artery catheterization. A report by the American Society of Anesthesiologists Task force on pulmonary artery catheterization. Anesthesiology 1993; 78: 380-94.

16. Lyons G. Failed intubation. Anaesthesia 1985; 40:759-62.

17. Ankichetty SP, Chin KJ, Chan VW, Sahajanandan R, Tan H, et al. Regional anesthesia in patients with pregnancy induced hypertension. J Anaesthesiol Clin Pharmacol 2013;29:435-44.

18. Bateman BT, Polley LS. Hypertensive disorder. Dalam: Chesnut DH, editor. Chesnut's Obstetric Anesthesia: Principles and Practice. 5th ed. Philadelphia: Saunders Elsevier; 2014; 825-59.

19. Ngan KW, Khaw KS, Ma KC, Wong $\mathrm{AS}$, Lee $\mathrm{BB}, \mathrm{Ng} \mathrm{FF}$, et al. Maternal and neonatal effects of remifentanil at induction of general anesthesia for cesarean delivery. Anesthesiology. 2006;104(1):14-20.

20. Eisele JH, Wright R, Rogge P. Newborn and maternal fentanyl levels at cesarean section. Anesth Analg 1982;61:179-80. 